\title{
Nation Branding: An Analysis of Botswana's National Brand
}

\author{
Edward E. Marandu (Corresponding author) \\ University of Botswana \\ Faculty of Business, Marketing Department, \\ P. O. Box 70243, Gaborone, Botswana \\ E-mail: marandue@mopipi.ub.bw \\ Donatus N. Amanze \\ University of Botswana \\ Faculty of Business, Marketing Department, \\ P. O. Box 70243, Gaborone, Botswana \\ E-mail: donatus.amanze@mopipi.ub.bw \\ Tirubaza C. P. Mtagulwa \\ University of Botswana \\ Faculty of Business, Marketing Department, \\ P. O. Box 70243, Gaborone, Botswana \\ E-mail: mtagulwat@mopipi.ub.bw
}

Received: August 24, 2011

doi:10.5430/ijba.v3n2p17
Accepted: February 19, 2012 Published: March 15, 2012

URL: http://dx.doi.org/10.5430/ijba.v3n2p17

\begin{abstract}
This paper evaluates Botswana's national branding using the Gilmore (2002) and the Echtner \& Ritchie (2003) models. The methodology involved an examination of the extant literature to identifying key factors that influence brand perceptions for a nation and the nature of those factors. The findings showed that the Botswana branding incorporated most of the variables depicted in the Gilmore model. The nature of the variables chosen were also consistent with the Echtner and Ritchie model in the sense that it made use of functional and psychological characteristics and combined them in a holistic manner to come up with the slogan "our pride, your destination". The paper advises future researcher to empirically test the robustness of the Botswana brand in terms of its effectiveness on the ground.
\end{abstract}

Keywords: Branding, Gilmore Model, Echtner \& Ritchie Model, Botswana

\section{Introduction}

The concept of branding has traditionally been associated with companies and their products or services, but nowadays the concept is being used in the shaping of reputation of nations. It is a somewhat new way of looking at a nation, but every nation is already a brand for it has a way it is perceived in the minds of people living elsewhere, at least those people who are aware of its existence (Kyriacou and Cromwell, 2004). Some countries are known for good things, some for bad, and some are mixed. Based on these perceptions, other nations and individuals interact with a nation, either contributing to its development or hindering it. For example Africa is associated with civil war, Iraq with suicide bombings and Cuba with Fidel Castro's dictatorship. On the contrary countries such as the US, UK or France, have acquired positive perceptions through decades of sound political and economic development (Kyriacou and Cromwell, 2004).

Nation branding is based on the underlying assumption that every nation is a brand; either attained through its conscious effort or created by chance. The important thing to realize about branding a nation is that an important ingredient of nation branding is the amplification of something that is to be found already within that nation, and not a fabrication. A 
nation's brand positioning cannot be an artificial creation, imposed from the outside. A nation's brand should be rooted in reality and in fundamental truths about the nation. The intensification of a particular characteristic may help diminish some of the stereotypical perception about a certain nation. Thus designing a good nation brand must be based on realistic positive values and perceptions already existing in any given nation.

The problem is that most countries have their brands made for them by others or by good or bad fortune. Events in a nation as described by historians and the mass media shape perceptions about a nation. A nation with good tourist attractions and endowed with exportable goods is likely to enjoy a positive image in the world, an identity that will serve to make it an attractive place to visit, invest and live. On the other hand, a nation torn by civil war, lacking the rule of law and basic infrastructure is likely to be judged a high risk place for visiting, investing and living. The purpose of nation branding is therefore not to risk leaving the nation brand perception building process to others or to chance, but consciously position a nation in the best way possible in the world system, given its strengths and weaknesses.

In commercial contexts "a brand is a name, term, sign, symbol, design or a combination of them, intended to identify the goods and services of one seller or group of sellers and to differentiate them from those of competition" (Kotler, 2002). A nation brand is the same but applied to a whole nation. The aims are broad-based such as to promote exports, inbound foreign direct investment, tourism or a combination of them. Thus nation branding is a field of theory and practice that applies commercial brand management theory and practice to countries, in an effort to build, change or protect their international reputations (Wikipedia, 2007). It is based on the observation that the image of a nation is just as important to success in the global marketplace as that of products and services.

Nation branding is a relatively new area of study. On the contrary, studies on the related concept of country-of-origin make it one of the most researched issues in international buyer behavior (Tan and Farley, 1987; Papadopoulos and Heslop, 2002). However, despite research volume on country-of-origin, the collective worth of these studies is limited because there is little contribution towards understanding of the constructs involved especially those that could be operationalised in research. To some analysts country-of-origin and nation branding are synonymous. It is necessary at this juncture to attempt a conceptual clarification of these key terms. These terms refer to two levels of analysis: product level and national level. Country-of-origin and similar concepts are closely related to a product. The product-nation image is embedded as part of the product brand, and is meaningless if separated from the product (Fan, 2006). On the other hand the concept nation brand refers to the nation as a whole; it describes the nation's reputation without an explicit link to a product. In other words country-of-origin is a subset of nation brand (Kotler, 2002).

There is no single generally accepted definition of nation branding. To some it refers to a consistent and all embracing national strategy which determines the most realistic, most competitive and most compelling strategic vision for the nation, and ensures that this vision is supported, reinforced and enriched by every act of communication between the nation and the rest of the world (Anholt, 1998). To others a nation brand is a generic label or ubiquitous wrapper that can become the compelling glue between political, social and economic pillars of a nation (Nation brand Index ...., 2007). Brand, when properly conceived and executed, can elevate a nation, focus its tourist offering, fuel it's outbound and inbound investment, reframe its reputation and create renewed pride among its citizens.

Yet to others a nation brand may be defined as "the way a nation is perceived by its audience" (SourceWatch, 2007). It is important to emphasize, however, that audience is split into two main groups: that nation's people and everyone else. It appears that most nation branding programs aim at improving a nation's reputation in the eyes of the rest of the world. But it is equally important to create programs that aim at that nation's own people for two reasons. First, behavior of its people also influences the way a nation is perceived by foreigners. Second, the reputation of a nation among its citizens is important to local producers who compete in the local market for it affects how local consumers view products made in the nation compared to those made abroad.

The purpose of this paper is to evaluate Botswana's national brand using the conceptual models of Gilmore (2002) and Echtner \& Ritchie (2003). The paper seeks to highlight the critical determinants of nation branding and enrich the existing body of literature within the context of Botswana. Research on branding Botswana is timely for it can provide inputs into the on-going branding Botswana exercise either at the implementation or review stages.

\section{Background to the Study}

In May 2006 His Excellency the then President, Mr. Festus Mogae officially launched the process to develop a nation brand as part of a strategy to promote investment, tourism and the nation's image. A consortium of economic development and branding experts (Kaiser Associates and Place brands) were tasked with developing a detailed brand strategy and implementation plan for the roll-out of Botswana nation brand. In order to build a meaningful brand for Botswana, it is important to have a good understanding of the status quo - the actual economic, political, social and 
cultural situation. This is so because while branding may be able to help a nation improve its communication with the world, it won't work if the nation sends out lies or hype (Joachimsthaler, 2007). The status quo acts as the "accidental brand" or point of reference for the development of a new brand designed to achieve the brand objectives for the nation.

\subsection{Botswana - Performance Record}

Botswana celebrated 45 years of freedom in 2011. It is time to celebrate remarkable achievements made in this period as well as reflect on challenges that threaten the sustenance of much of these successes. Botswana can and should surely feel proud of its achievements in social-political and economic terms since independence.

\subsubsection{Economic Achievements}

- Botswana is one of the world's leading performers in terms of per capita income growth, recording an annual growth rate of about 7.2 percent in 2010 (CIA, 2011) sometimes exceeding that of the Asian Tigers (Jolly, 1997).

- At independence in 1966, Botswana was amongst the world's poorest twenty countries in terms of per capita income, at BWP70 equivalent to US\$12 (UNDP, 2005). Through fiscal discipline and sound management, the nation has transformed itself from one of the poorest countries in the world to a middle-income nation with a per capita income of US\$3,056 in 2004 (The World Fact Book, 2005).

- Due to Botswana's track record for prudent economic management and the resulting build up of substantial financial reserves, the country has consistently been awarded 'investment grade' ratings which are the highest in Africa. This is despite the recent global recession which resulted in a ratings downgrade by Standard and Poors due to the impact on export earning and government revenues (Bank of Botswana, 2012).

- Producers in Botswana have access to the South African market because of Botswana's membership of Southern African Customs Union (SACU), and to the Zimbabwe market because of the 1956 trade agreement (Siphambe, 2003). These arrangements allow for preferential exchange and flow of goods between the trading partners.

- Botswana has made good use of its unique tourism attractions. Botswana's tourism is concentrated both in terms of types of attractions and their geographical distribution (Kaynak and Marandu, 2006). Wildlife is the dominant attraction and is concentrated in two areas located in the north-west part of the nation. The first area is the Okavango Delta, the largest in-land delta in the world, which is a unique area of lagoons, reed-fringed waterways and islands. The second area is the Chobe-Kasane National Park. All of Africa's big five game (elephants, lions, buffalos, leopards, rhinos) are available in abundance. Although there has been limited development to date of other tourism attractions, the Government plans to diversify the nation's tourism product away from endowed attractions into cultural, historical and other manmade attractions.

\subsubsection{Social-Political Achievements}

- The nation is an icon of democracy and stability in Africa. It is the only nation in Africa that adopted multi-party democracy right from independence, with elections every five years, which have always been regarded as free and fair.

- Improved educational and health facilities for most of the 45 years of independence led to commendable social gains including lowering the under-five mortality rate, raising life expectancy and increasing contraceptive prevalence. Moderate progress has been made in the eradication of poverty. The poverty figure is declining: from 59\% (1985) to $47 \%$ (1994) to 37\% (2001) and declined further to 23\% in 2009 (MFDP, 1996; Merafhe, 2010).

\subsection{Botswana - Major Challenges}

Despite the significant achievements made, a number of challenges exist that threaten much of Botswana's successes as a stable and prosperous African nation. These are as follows:

- In spite of efforts of the past two decades to diversify, the economy is dominated by the non-renewable commodity, diamond. Diamonds contribute 33\% of GDP. Agriculture has declined from $50 \%$ in 1966 to only $2.4 \%$ in 2003 (Development and Energy in Africa .., 2007). The following figures are more revealing: diamonds earn $95 \%$ of foreign exchange earnings and constitute $50 \%$ of Government revenue. Over-reliance on the mineral sector has negative implications that include high unemployment (mining is capital intensive) that stood at 17.3\% in 2006 (Siphambe, 2007) and other sectors of the economy have suffered relative neglect and underdevelopment.

- The spread of the HIV/AIDS pandemic is posing a major challenge to the Government. The infection rate of $17 \%$ has forced Government to divert a significant share of the national budget to combat the pandemic. These are resources that could have been devoted to development where employment could be created. 


\subsection{The Benefits of Nation Branding}

The development and sustenance of the domestic manufacturing sector in a free economy is dependent on the global consumer acceptance of the goods manufactured in a country. Consumers often use the source country of a product or brand as an extrinsic information cue when making product evaluations. A nation can behave just like a manufacturer's brand, providing trust and a guarantee of quality (Laforet, 2010:369). Like any brand, countries have individual fingerprints that are unique. This uniqueness gives power to a national brand. The national brand can influence the positioning and differentiation of a nation's many products. Therefore a country that enjoys a positive brand image will be attractive to investors, tourists and importers.

Specifically, a country's brand image will have implications for domestic manufacturers, foreign manufacturers, marketers, exporters and other channel intermediaries doing or wishing to do business in that country. On the general level, a country's image has implications for a developing country government such as Botswana that is trying to establish domestic manufacturing competency in the face of competition from established foreign brands from advanced countries. The concept of nation brand equity means that brands are seen as valuable assets to the country which enables it to stand out in the comity of nations.

One author (Laforet 2010) suggested that brand equity is made up of four main elements: brand name awareness, brand loyalty, perceived quality and brand associations. Of the four elements, the most relevant in country branding is the brand associations. This is why negative connotations are often associated with developing nations, while positive ones are associated with developed nations. It is therefore necessary to properly brand a country so as to not only elevate the country but to improve its reputation and create pride among its citizens.

Powerful country brands that are carefully managed tend to yield benefits for tourism, politics and culture. Country branding yields several benefits. It can help a country to create a unique identity - a country identity means how a country sees itself and how others see it. This helps the country to build, project or reinforce positive image and also minimize negative images. Branding helps to provide a way of expressing positive national impressions and emotions and inspire behavioral change among the nationals (Sidhom, 2010). Specifically, nation branding should therefore enable Botswana to:

- Define and express its vision to the world;

- Position itself as a destination of choice for tourists, tour operators, the media, traders, investors, and residents;

- Highlight the country's offering in the areas of culture and heritage, governance and exports to audiences;

- Create and maintain a defined, consistent and single identity to effectively differentiate itself in the global market; and

- Address the major challenges such as diversification and attracting Foreign Direct Investment.

\section{A Conceptual Framework}

It is important to understand the salient factors that influence a nation's brand perception before attempting to evaluate how the concept has been applied in a specific situation. An examination of the extant literature reveals two main types of studies: studies that attempt developing a framework helpful in identifying key factors that influence brand perceptions for a nation and those that attempt to develop an understanding of the nature of those factors.

\subsection{Key Nation Branding Factors: The Gilmore Model}

An interesting model for identifying salient factors that influence a nation's brand is Gilmore's (2002) proposal that a nation's brand consists of a set of three layers. In this sense a nation brand can be described as being like an onion: a system that can be peeled, layer by layer, in order to reveal the content (Dahl, 2004). According to Gilmore a good nation brand must "sit at the heart of the nation", the inner layer (Figure 1). This means that the core of a nation's brand must capture the shared purpose or spirit of people in a nation. The shared purpose is founded on a number of factors including: values, culture, history, economy and the people's experiences. The author provides one example of this: the brand of Northern Ireland captures the shared purpose which is the people's genuine warm welcome, humor and sense of optimism.

The second layer consists of positioning that the nation can achieve basing on its shared values. Gilmore suggests that in addition to using shared values, a brand position can be developed after consideration and incorporating one or more of the following four essential factors, called the positioning diamond - macro trends, target groups, competitors and core competencies (Figure 2). Macro trends affecting a nation include socio-economic trends, political and legal status, population trends, cultural and lifestyle trends and emerging industries. The study of macro trends places the current situation of the nation into proper context and helps to highlight the issues the nation is facing and could face in the future. Understanding the potential target audiences forces the branding team to focus on whom the nation is trying to 
attract. Understanding the competitive landscape is helpful on understanding which competitors are credible and deciding on whether to position the brand against or away from them.

Core competencies that can be used in nation brand positioning are physical or human assets. For example, a nation such as Botswana is well known for its huge deposits of diamonds - a physical core competency linked to the fact that Africa is one of the oldest land masses on earth and Botswana happens to be sitting on that part of it which holds diamonds. Such a core competency gives the nation a specific advantage that cannot be replicated by another nation unless the same physical conditions and tectonic movements took place there. In terms of human assets, brand positioning can use exceptional individuals such as visits by two American presidents (Clinton in 1998, Bush in 2003) and election of a Motswana as Miss Universe in 1999 which provide unprecedented favorable exposure of the nation and have the potential to bring a nation's brand alive and make it more real to audiences worldwide. This positioning works for the simple fact that people relate to people.

Producing a meaningful positioning is the most difficult part of the branding exercise because it needs to be 'aspirational, inspirational, challenging, differentiating and translatable' for the different audiences. The first two aspects, aspirational and inspirational mean that a nation's brand will not get off the ground unless it captures hearts and minds. This is so because unlike in an organization, where employees constantly think and use their corporate brand in their day-to-day work, there is no similar pressure for the people of a nation to think and use their nation's brand.

The aspect of 'challenging' is to ensure that the positioning is forward looking, energized and stretching. The aspect of 'differentiation' is to ensure that the positioning is not generic in the global marketplace; instead the nation brand position should ideally act as a national umbrella brand, seeking to distinguish the nation's products from international competitors (O'Shaughnessy and O'Shaughnessy, 2000). The need for a 'translatable' positioning is because a nation has different stakeholders to be served with its brand. These stakeholders are presented in the third layer and include visitors, residents, investors, students, retirees and opinion formers. The positioning must therefore be sufficiently robust for adaptation into multifaceted sub-positioning with relevance for each key stakeholder, and yet retain its integrity by staying true to the shared purpose, core values and spirit of the nation. This last aspect holds great importance because one of the great difficulties of nation branding is the diversity of its various audiences.

To illustrate, Hong Kong developed a brand that has at its core the 'hoh yi' or 'can-do' spirit or shared purpose which was discerned through research undertaken with $250 \mathrm{CEOs,} \mathrm{opinion} \mathrm{formers} \mathrm{and} \mathrm{workshops} \mathrm{with} \mathrm{students.} \mathrm{One} \mathrm{general}$ positioning that was derived from this core value was that of 'Hong Kong-Boundless Possibility' which is the unstoppable energy of the people. This concept is thought to be aspirational, inspirational and challenging. This positioning was considered translatable or adaptable for relevance to various stakeholders, be they tourists, investors, students or residents.

\subsection{The Nature of Factors: Echtner and Ritchie Model}

The literature capturing the nature of nation branding factors can be found in studies that measure destination image. Several contributions to the understanding of the nature of factors that are used for nation branding come from studies that attempt to measure image of tourist destinations (Hunt, 1975; Gallarza, Saura and Garcia, 2002:58; Pike, 2002). One major contribution (Echtner and Ritchie, 2003) was seminal for it derived the following influential conclusions:

- Destination image has two main components: perception on functional characteristics, concerning the more tangible aspects of the destination for example, prices and climate and perception on psychological characteristics, concerning the more intangible aspects such as friendliness, atmosphere (Figure 3).

- Each of these components can be classified into perceptions on individual destination attributes and the holistic impression made by the combination of those attributes about a destination.

- Each of the components can be classified further as common or unique. For example, a destination's image can include ratings on certain common functional characteristics, such as price levels, transportation infrastructure, types of accommodation and climate. In regard to unique characteristics, for instance, India may evoke an image of the Taj Mahal, California of Disneyland, Brazil of the Amazon Jungle and, Nepal of Mt. Everest, Botswana of Okavango Delta.

While this conceptualization appears to divide branding into four distinct components, it should be noted that there are obvious overlaps and conceptual difficulties between the components. In regard to overlap, the dividing line between functional and psychological characteristics is not clear. With regard to conceptual difficulties, questions have been raised as to the virtues of measuring holistic impressions because they are based on a combination of individual attributes. Others (Bigné, Sámchez and Sánchez, 2001:611) have argued that the sum of the attribute scores is not an adequate measurement of the overall image. Yet others go further and suggest that attribute-only based studies exhibit 
some shortcomings because they cannot capture the holistic nature and subjective perspective of the individual, nor the destination's unique characteristics of the image (Echtner and Ritchie 2003; Tapachai and Waryszak 2000).

\subsection{Synthesis: Gilmore, Echtner and Ritchie Models}

An analytical model, which provides a framework for the study was constructed as shown in figure 4 . The model borrowed its core concepts from the Gilmore model. In the model, brand perceptions that a nation attains is conceptualized as a function of the perceived attractiveness of a nation on three areas: as a place to visit, a place to do business and as a place to live. These three main areas are all linked to Botswana's major objectives of economic diversification through increase of inward-bound tourism, attraction of inward investment and improvement in the quality of life of its citizens.

The three areas represent different levels of involvement from virtually zero, when the individual merely makes one-off visit to a nation to total involvement where the individual decides to stay in a nation through being born there or immigration. Even within each broad measure there can be a wide variation in the levels of involvement. For example, on deciding to do business with a nation one might have minimal involvement by merely making the products available for others to export to that nation to total involvement where the firm might operate a subsidiary in the nation.

This conceptualization is not entirely new. In fact Kotler, Hamlin, Rein and Haider (2002:231), when discussing how to measure the perception towards a place, wrote about "broad audiences that might be interested in visiting, working or investing and living in a place and they may hold varying perceptions of it". Its implication in nation branding is that to develop a robust brand image of a nation, efforts must be directed at these three broad audiences.

Following from the foregoing discussion we conclude that the following principles should apply in branding Botswana:

- The variables used must be robust in the sense that when the brand is generated it can appeal directly or after adaptation to the different major audiences, namely visitors, investors and residents.

- The variables used should have the following characteristics: functional as well as psychological significance; single attribute as well and holistic impression; those common to most countries and those unique to Botswana.

- A good nation brand should be aspirational, inspirational, challenging and differentiating.

- The variables used for one target group are not necessarily mutually exclusive. For example many of the factors that entice a person to visit a place such as climate or infrastructure will also entice a person to do business there or live there permanently.

This review study does not attempt to develop a brand statement for the situation in Botswana. Instead, it evaluates current brand statement in regard to the key areas for nation branding as seen by Gilmore (2002) and Echtner and Ritchie (2003) to see how well the key drivers have been incorporated into the Botswana branding.

\section{Evaluation of the Botswana Brand}

\subsection{Evaluation based on the Gilmore Model}

The "Our pride, your destination" brand was launched in April 2010 with three key Botswana values which are tranquility, home grown and work well. It tells about the experience of living, studying, working, visiting or doing business in the country. Table 1 contains a comparison of the salient variables that were used in the formulation of the Botswana National Brand as compared to those stipulated in the Gilmore Brand Model. The Table reveals the following four important points:

1. First, the Botswana branding process incorporated the three layers of the Gilmore model though they are called by different names. While Gilmore calls these "spirit of the people", "positioning diamond" and "stakeholders", the Botswana branding team calls these "attributes", "differentiators" and "stakeholders", respectively.

2. In regard to the variables that constitute the innermost layer, Botswana incorporated three of the five variables of the Gilmore Model except "culture" and "people's experiences". However, Botswana seems to have introduced a new element of branding which is personality.

3. In the middle layer Botswana used three of the four variables which are used by Gilmore to make the "positioning diamond" but omitted "target groups".

4. In the third and outer layer comprising of stakeholders the variables taken into consideration by Gilmore and the Botswana team are practically the same, although called by different names. However, Gilmore includes opinion formers / media which is not captured explicitly in the Botswana model. On the other hand Botswana included Non-Governemental Organizations which are not captured in the Gilmore model. 


\subsection{Evaluation based on the Echtner and Ritchie Model}

The ideas inherent in the Echtner and Ritchie Model (2003) seem to be incorporated in the Botswana branding exercise in the following ways:

1. The functional characteristics such as economic growth, democracy, good governance and educational standards were taken into account.

2. Psychological factors such as peace, friendliness and gender equality were taken into account.

3. These functional and psychological characteristics were combined together (holistic) in the branding process to create a positive image which is translated into the slogan "Our pride, your destination".

\subsection{Strengths and Limitations of the Gilmore Model}

The Gilmore model, especially the positioning diamond, is valuable because it forces an analyst to assess the priorities of the branding exercise, to think broadly as well as to narrow the parameters governing the development of a nation's brand. On the other hand, there are limitations inherent in the model.

1. First, the variables making this model stand-alone; they lack a clear theoretical underpinning factor tying the variables together. There is no description of the underlying characteristics of the variables in the three layers used. It is not clear whether the various levels to branding, range from the easily observable outer layer (stakeholders) to the increasingly more difficult to grasp inner layers (such as values).

2. Second, the variables in three layers are not well defined and conceptually or empirically distinct for certain variables fall into two or more layers. For example "economy" is a variable that constitutes the spirit of the nation, in the inner layer, but it is also included in the middle layer as part of "macro trends". Similarly "target groups" is a variable found both in layer two and also in outer layer but with a changed name into "stakeholders".

3. Finally, the Gilmore model focuses on creation of a brand, and does not provide direction in relation to implementation or evaluation of the brand once created.

\subsection{Conclusions}

1. From the theoretical point of view, the Botswana branding has incorporated most of the variables depicted in the Gilmore model.

2. The Botswana branding variables are consistent with the Echtner and Ritchie model in the sense that it made use of functional, psychological characteristics and combined them in a holistic manner to come up with the slogan 'our pride, your destination'. However, actual slogan seems to target mainly external rather than internal stakeholders.

3. Taking the Gilmore and the Echtner and Ritchie models as standards in national branding, then it seems that the Botswana national branding team performed well in terms of capturing the salient variables for consideration in national branding.

4. Future researchers are advised to empirically test the robustness of the Botswana brand in terms of its effectiveness on the ground.

\section{References}

Anholt, S. (1998). Nation-Brands of the Twenty-First Century. Journal of Brand Management. 5(6), 395-406.

Bigné, J. E. Sámchez, M. I. \& Sánchez, J. (2001). Tourism image, evaluation variables and after purchase behaviour: inter-relationship. Tourism Management. 22 (6), 607-616. http://dx.doi.org/10.1016/S0261-5177(01)00035-8

CIA (2011). CIA World Factbook [Online] Available: https://www.cia.gov/library/publications/the-world-factbook/ (February 17, 2012).

Dahl, S. (2004). Intercultural Research: The Current State of Knowledge. Social Science Research Network . 30( 7): 1153-1174.

Development and Energy in Africa .... (2007). Development and Energy in Africa (DEA) project: A case for Botswana. [Online] http://deafrica.net/workshops/Botswana\%201/Botswana\%20National\%20Background\%20Paper.doc (February 24, 2007).

Echtner, C. M. \& Ritchie, J. R. B. (2003). The Meaning and Measurement of Destination Image. The Journal of Tourism Studies. 14(1): 37-48.

Fan, Y. (2006). Branding the nation: What is being branded? Journal of Vacation Marketing. 12(1): 5-14. http://dx.doi.org/10.1177/1356766706056633 
Gallarza, M. G., Saura, G. \& Garcia, C. H. (2002). Destination Image: Towards a Conceptual Framework. Annals of Tourism Research. 29(1): 56-78. http://dx.doi.org/10.1016/S0160-7383(01)00031-7

Gilmore, F. (2002. A Nation - Can it be Repositioned? Spain-the Success Story of Nation branding. Journal of Brand Management. April, 9(4/5): 281-91.

Hunt, J. D. (1975). Image as a Factor in Tourism Development. Journal of Travel Research. 13(3): 1-7. http://dx.doi.org/10.1177/004728757501300301

Joachimsthaler, E. (2007). Quoted by SourceWatch (2007). Nation branding. [Online] Available: http://www.sourcewatch.org/index.php?title=Nation_branding (March 2, 2007).

Jolly, R. (1997). Keynote Address: Triumphs and Challenges from a Human Development Perspective. In Nteta, D. Hermans, J. Jeskova, P. (Eds.). Poverty and Plenty: The Botswana Experience. Proceedings of a Symposium organised by The Botswana Society, October 15-18, 1996 Gaborone, Botswana. Gaborone: Published by the Botswana Society.

Kapferer, J. N. (1998). Strategic brand management. London: Kogan Page.

Kaynak, E. Marandu, E. E. (2006). Tourism Market Potential Analysis in Botswana: A Delphi Study. Journal of Travel Research. 45(2): 227-237. http://dx.doi.org/10.1177/0047287506291595

Kotler, P. (2002). Nation as Brand, Product and Beyond: A Place Marketing and Brand Management Perspective. Journal of Brand Management. 9(4/5): 249-61. http://dx.doi.org/10.1057/palgrave.bm.2540076

Kotler, P., Hamlin, M. A. Rein, I. \& Haider, D.H. (2002). Marketing Asian places: attracting investment, industry, and tourism to cities, states, and nations. Singapore: Wiley \& Sons.

Kyriacou, S. \& Cromwell, T. (2004). Branding nations the concepts and benefits of nation branding. [Online] Available: http:// www.eastwestcoms.com (January 12, 2011).

Laforet, S. (2010). Managing brands. London: McGraw-Hill.

Merafhe, M. (2010). Government Steps Up Drive to Eradicate Poverty. [Online] Available: http://www.gov.bw/en/News/Government-steps-up-drive-to-eradicate-poverty/ (February 17, 2012)

MFDP - Ministry of Finance and Development Planning (1996). Study of Poverty and Poverty Alleviation. Gaborone: Government Printer.

Nation brand Index ..., (2007). Nation brand index. [Online] Available: http://www.nationbrandindex.com/ (April 21, 2007).

O’Shaughnessy, J. \& O’Shaughnessy, N.J. (2000). Testing the nation as a brand: some neglected issues. Journal of Macromarketing. 20(1): 56-64. http://dx.doi.org/10.1177/0276146700201006

Papadopoulos, N. \& Heslop, L. (2002). Nation equity and nation branding: Problems and prospects. Journal of Brand Management, 9(4/5): 294-314. http://dx.doi.org/10.1057/palgrave.bm.2540079

Pike, S. (2002). Destination image analysis - a review of 142 papers from 1973 to 2000. Tourism Management. 23(5): 541-549. http://dx.doi.org/10.1016/S0261-5177(02)00005-5

Sidhom, S. (2010). How do you build a country brand? [Online] Available: http://nation-branding.info/2010/03/24/how-do-you-build-a-country-brand/ (June 8, 2011).

Siphambe, H. K. (2003). The Implications of Globalisation for Foreign Direct Investment in Botswana. Paper Presented at the South African Economic Association Biannual Conference, September 17. [Online] Available: http://www.essa.org.za/download/2003Conference/SiphambeHK_\%20The\%20Implications\%20Of\%20Globalisatio $\mathrm{n} \% 20$ For\%20Foreign\%20Direct\%20Investment\%20In\%20Botswana.pdf (March 21, 2007).

Siphambe, H. K. (2007). Growth and Employment Dynamics in Botswana: A case study of policy coherence. Geneva: ILO.

Source Watch (2007). Nation branding. [Online] Available: http://www.sourcewatch.org/index.php?title=Nation_branding (March 2, 2007).

Tan, C.T. Farley, J.U. (1987). The impact of cultural patterns on cognition and intention in Singapore. Journal of consumer research. 13(March): 540-544. http://dx.doi.org/10.1086/209087

Tapachai, N. \& Waryszak, R. (2000). An Examination of the Role of Beneficial Image in Tourist Destination Selection. Journal of Travel Research. 39(1)August: 37-44. http://dx.doi.org/10.1177/004728750003900105 
The World Fact Book (2005). The World Fact Book. [Online] Available: http://www.cia.gov/cia/publications/factbook/geos/bc.html (December 20, 2005).

Wikipedia, the Free Encyclopedia (2007). Nation branding. [Online] Available: http://en.wikipedia.org/wiki/Nation_Branding (March 6, 2007).

Table 1: $\quad$ Gilmore Model and Botswana Branding

\begin{tabular}{|c|c|}
\hline Gilmore Model & Botswana Nation Branding Factors \\
\hline $\begin{array}{l}\text { Spirit of the people: } \\
\text { - Values } \\
\text { - History } \\
\text { - Economy } \\
\text { - Culture } \\
\text { - People's } \\
\text { experiences. }\end{array}$ & $\begin{array}{l}\text { Attributes: } \\
\text { - Value. Peaceful, trustworthy, progressive and inclusive. } \\
\text { - } \quad \text { History. Good governance, democratic, transparent govt, gender } \\
\text { equality. } \\
\text { - } \quad \text { Economy. Economic stability and growth. } \\
\text { - Personality. Friendly, reliable, optimistic, innovative and } \\
\text { confident }\end{array}$ \\
\hline $\begin{array}{l}\text { Positioning Diamond: } \\
\text { - Macro trends, } \\
\text { - Core competencies } \\
\text { - Competitors } \\
\text { - Target groups }\end{array}$ & $\begin{array}{l}\text { Differentiators: } \\
\text { - Macro trends. Economic, social and political stability. } \\
\text { - Core competencies. Diamond and beef industry, high literacy rate, } \\
\text { good governance and education standards. } \\
\text { - Competitors. Competitors categorized according to their } \\
\text { offerings; Tourism: South Africa, Namibia Kenya and Zambia } \\
\text { Diamond: Russia Beef: Brazil, Argentina Textile and food production: } \\
\text { China and India Foreign Investment: Mozambique and Tanzania. }\end{array}$ \\
\hline $\begin{array}{l}\text { Stakeholders: } \\
\text { - Visitors } \\
\text { - Residents } \\
\text { - Investors } \\
\text { - Students } \\
\text { - Retirees } \\
\text { - Opinion formers }\end{array}$ & $\begin{array}{l}\text { Stakeholders: } \\
\text { - Tourists } \\
\text { - Batswana: Local community } \\
\text { - Local business community } \\
\text { - Investors: International business community } \\
\text { - Trade partners } \\
\text { - NGO's. }\end{array}$ \\
\hline
\end{tabular}




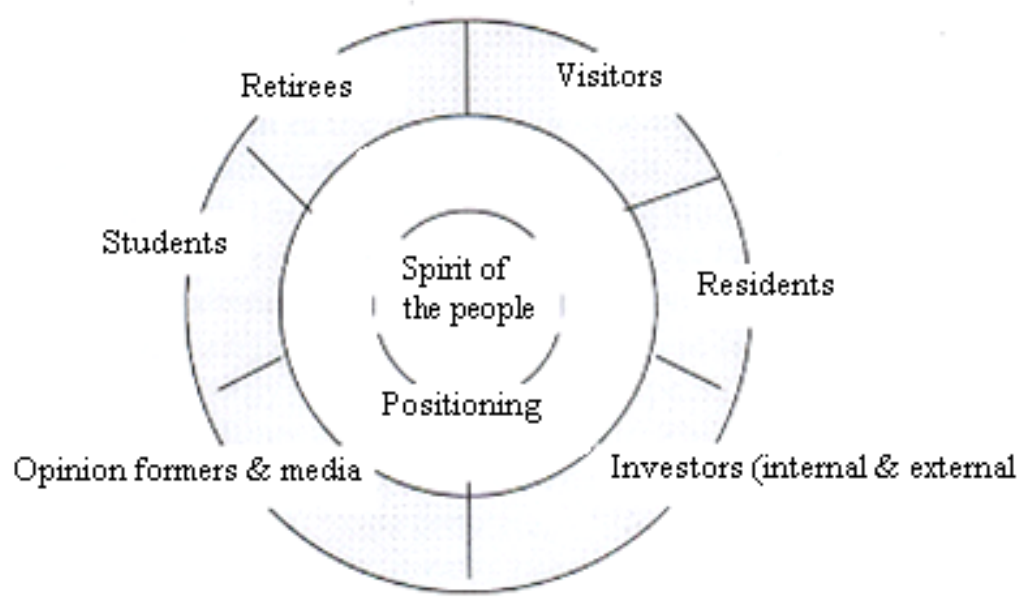

Figure 1. A Framework for Nation branding Source: Gilmore (2002).

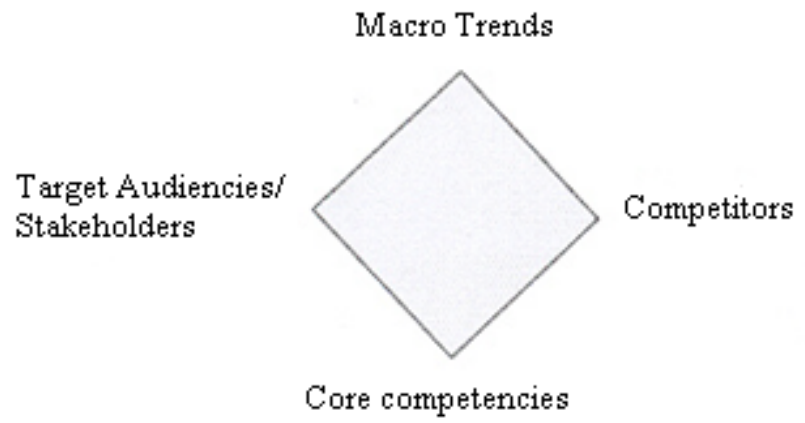

Figure 2. Positioning Diamond Source: Gilmore (2002). 


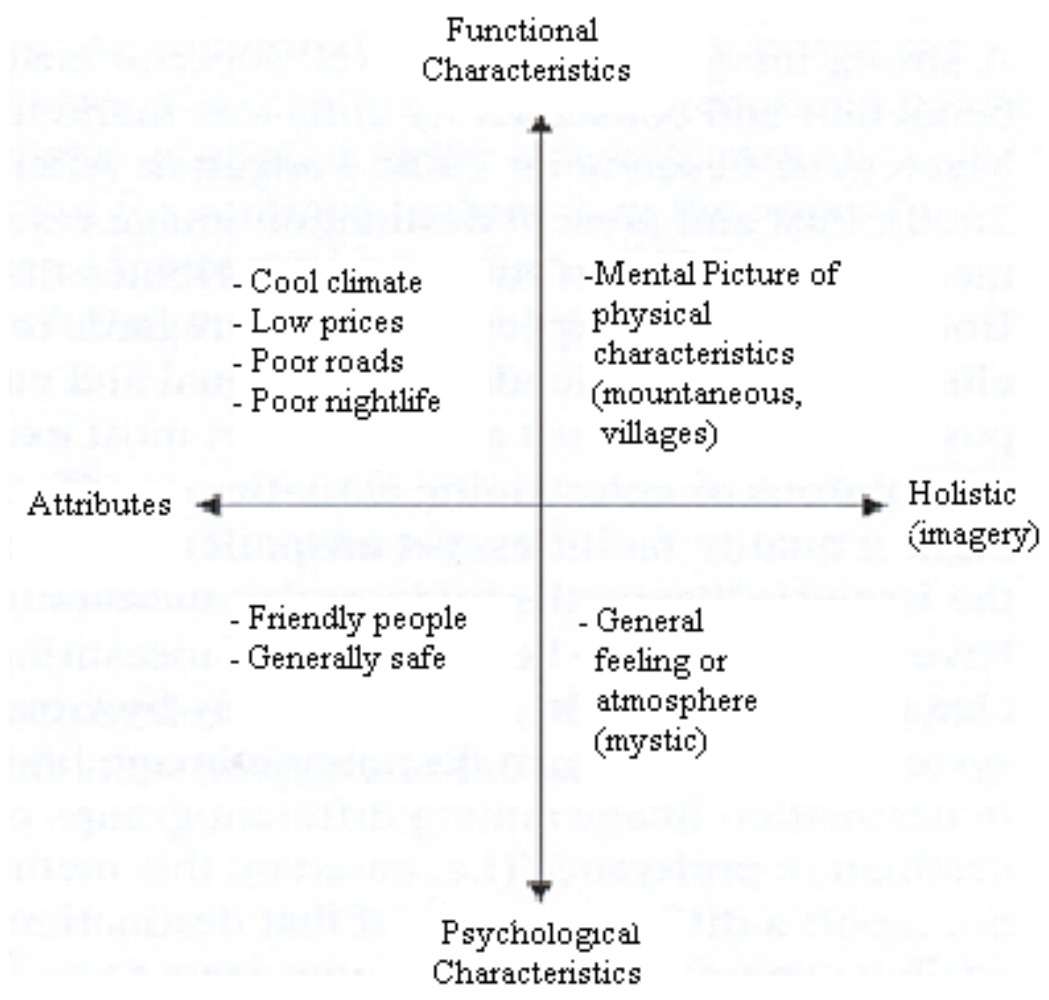

Figure 3. Components of Destination Image

Source: Echtner and Ritchie, 2003.

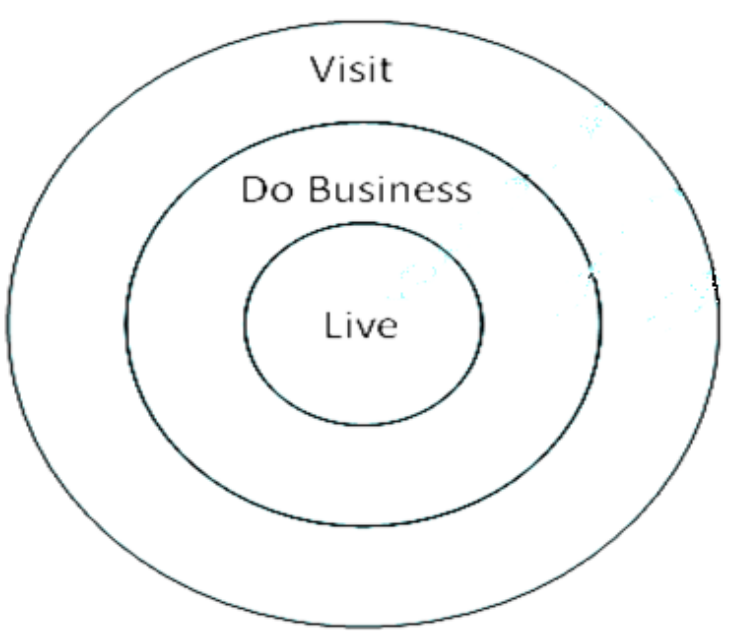

Figure 4. A Model of Nation Branding 